\title{
УДК 81'23:808.51
}

ЧЕРНИШОВА Таїсія - кандидат філологічних наук, дочент, дочент кафедри філософії, Харківський національний університет Повітряних Сил імені Івана Кожедуба, вул. Сумська, 77/79, Харків, 61023, Україна (taisya76@ukr.net)

ORCID: https://orcid.org/0000-0001-5299-8421

DOI: https://doi.org/10.24919/2522-4565.2021.46.18

Бібліографічний опис статті: Чернишова, Т. (2021). Політичний дискурс Президента України Володимира Зеленського: стратегії \& тактики мовленнєвого впливу (на матеріалі виступів першого року президентства). Проблеми гуманітарних наук: збірник наукових пращь Дрогобицького державного педагогічного університету імені Івана Франка. Серія "Філологія», 46, 147-156. doi: https:// doi.org/10.24919/2522-4565.2021.46.18

\section{ПОЛІТИЧНИЙ ДИСКУРС ПРЕЗИДЕНТА УКРАЇНИ ВОЛОДИМИРА ЗЕЛЕНСЬКОГО: СТРАТЕГІЇ \& ТАКТИКИ МОВЛЕННСВОГО ВПЛИВУ (НА МАТЕРІАЛІ ВИСТУПІВ ПЕРШОГО РОКУ ПРЕЗИДЕНТСТВА)}

Анотація. Метою дослідження є характеристика політичного дискурсу Президента України Володимира Зеленського периого року кадениії. У проиесі дослідження застосовано комплекс методів, щз зумовлено багатогранністю мовленнєвої діяльності Президента України: дискурсивний аналіз; когнітивний аналіз; концептуальний аналіз; інтент-аналіз.

Політичний дискурс В. Зеленського переважно визначають стратегія на підвищення i стратегія театральності. Стратегія на підвищення використана з метою створення навколо себе та своєї політичної сили позитивного ментального простору, тому реалізується за допомогою тактики аналіз-«плюс», що передбачає розбір політичної ситуації без експлічитного схвалення власного внеску, з демонстрачією вдячності пересічним громадянам. Стратегія театральності реалізується за допомогою тактики кооперації, яка експлікує намір ототожнити себе з народом. Прийомами тут є використання вокативів-етнонімів та інклюзивного займенника «ми», які беруть участь у конструюванні «ми-дискурсу» ŭ «усуспільненні» відповідальності; знижене буденне спілкування у форматі сторителінгу; транслінгвальна мовленнєва практика. Тактика іронізування проявляється у використанні стосовно політичних опонентів іронії з метою самопозиціонування і створення «маніпулятивного дискурсу позитиву».

Президентський дискурс В. Зеленського - складне мовленнєве утворення, характерними рисами якого є формат зниженого буденного спілкування у звертанні до украйнського народу; намір солідаризуватися з народом у вирішенні спільних проблем; репрезентація ціннісних орієнтирів молодіжної лінгвоспільноти; поширення публічних меседжів за допомогою соиіальних мереж; актуалізачія в мовленні фізіологічних і сочіальних потреб людей; перформативна функиія іронії.

Ключові слова: політичний дискурс, стратегія на підвищення, стратегія театральності, «ми-дискурс», тактика кооперації, тактика іронізування, тактика аналіз-«плюс».

CHERNYSHOVA Taisya - Ph.D. in Philology, Associate Professor, Associate Professor at the Department of Philosophy, Ivan Kozhedub Kharkiv National Air Force University, 77/79, Sumska str., Kharkiv, 61023,Ukraine(taisya76@ukr.net)

ORCID: https://orcid.org/0000-0001-5299-8421

DOI: https://doi.org/10.24919/2522-4565.2021.46.18

To cite this article: Chernyshova, T. (2021). Politychnyi dyskurs Prezydenta Ukrainy Volodymyra Zelenskoho: stratehii \& taktyky movlennievoho vplyvu (na materiali vystupiv pershoho roku prezydentstva) [Political discourse of the President of Ukraine Volodymyr Zelensky: speech influence strategies \& tactics 
(on the speeches of the first year of the presidency)]. Problemy humanitarnych nauk: zbirnyk naukovych prats Drohobytskoho derzhavnoho pedahohichnoho universytetu imeni Ivana Franka. Seriia «Filolohiia»-Problems of Humanities. "Philology" Series: a collection of scientific articles of the Drohobych Ivan Franko State Pedagogical University, 46, 147-156. doi: https://doi.org/10.24919/2522-4565.2021.46.18 [in Ukrainian].

\section{POLITICAL DISCOURSE OF THE PRESIDENT OF UKRAINE VOLODYMYR ZELENSKY: SPEECH INFLUENCE STRATEGIES \& TACTICS (ON THE SPEECHES OF THE FIRST YEAR OF THE PRESIDENCY)}

Summary. The aim of this article is to describe the political discourse of Ukrainian President Volodymyr Zelensky during his first year on the post. In the course of the research a set of methods was used, which is due to the versatility of the activity's speech of the Ukraine's President: discursive analysis; cognitive analysis; conceptual analysis; intent analysis.

$V$. Zelensky's political discourse is mainly determined by the strategy for increase and the strategy of theatricality. The strategy for increase is used to create a positive mental space around oneself and one's political force, so it is implemented through the tactics of analysis- "plus", which involves analyzing the political situation without explicit approval of one's contribution, with gratitude to ordinary citizens. The strategy of theatricality is realized through the tactics of cooperation, which explains the intention to identify with the people. Techniques here are the use of vocativesethnonyms and the inclusive pronoun "we", which participate in the construction of "we-discourse" and "socialization" of responsibility; reduced everyday communication in the format of storytelling; translingual speech practice. The tactics of irony is manifested in the use of irony against political opponents in order to self-position and create a "manipulative discourse of the positive".

$V$. Zelensky's presidential discourse is a complex speech formation, the characteristic features of which are: the format of reduced everyday communication in addressing the Ukrainian people; intention to show solidarity with the people in solving common problems; representation of the values of the youth linguistic community; dissemination of public messages through social networks; actualization in speech of physiological and social needs of people; performative function of irony.

Key words: political discourse, strategy for increase, strategy of theatricality, "we-discourse", tactics of cooperation, tactics of irony, tactics of analysis- "plus".

Постановка проблеми. В умовах становлення якісно нової геополітичної системи, розвитку інформаційного суспільства, виникнення нових загроз у світі, що швидко змінюється, особливу увагу в науковців викликає постать політичного лідера як найвпливовішого комунікатора в політичному світові, усвідомлення того, як формується й удосконалюється його мовленнєва картина світу, як вона впливає на використання ним різних мовленнєвих стратегій, тактик i прийомів для забезпечення сугестивного та персуазивного впливу на своє оточення, супротивників і соратників, пересічних громадян країни. Політичний лідер як Homo loquens - це не абстрактний, усереднений еталонний носій мови, а конкретна індивідуальність, занурена в дискурс, що формує мету, план мовленнєвих дій, поведінку в дискурсі. Позаяк найвпливовішим політичним лідером у президентських, президентсько-парламентських і навіть парламентсько-президентських республіках $\epsilon$ президент, то завдання дослідити президентську риторику як засіб, за допомогою якого він користується даною йому владою для управління нацією, для розробки й доведення стратегічного курсу розвитку країни, формування всенародної його підтримки, є актуальним і продуктивним для сучасних лінгвістичних студій.

Аналіз останніх досліджень і публікацій. Інтерес дослідників до проблем політичної комунікації, що виявляється у великій кількості присвячених різним аспектам цієї теми публікацій (Гаврилова, 2017; Диманте, 2015; Макаренко, 2017; Михалёва, 2009; Смирнова, 2012; Чорна, 2013; Adair, 2019; Adolphsen, 2014; Crespo-Fernández, 2021; Freelon \& Wells, 2020), свідчить не лише про теоретичну значущість цієї галузі знань, а й про затребуваність результатів у багатьох прикладних контекстах, пов'язаних з інтересами цілих держав та окремих громадян. Предметом дослідження президентської риторики закордонними вче- 
ними стає вивчення жанрів президентського дискурсу поряд із дослідженням окремих президентських промов, риторичних рухів, процесів спічмейкінгу, природи президентських риторики й етики, сучасної політичної мови в контексті сприйняття новітньої реальності та соціально-політичних проблем. Проте варто констатувати, що у вітчизняній науці бракує грунтовних досліджень президентського дискурсу, а поодинокі розвідки в цій галузі здебільшого спрямовані на виявлення особливостей реалізації мовленнєвого впливу в дискурсивній практиці американських президентів. Тож актуальність дослідження вмотивована необхідністю вивчення риторичної практики українських президентів.

Метою статті $\epsilon$ характеристика політичного дискурсу Президента України Володимира Зеленського першого року каденції.

Конкретними завданнями пропонованого дослідження визначено аналіз тих дискурсивних стратегій і конкретних тактик чинного Президента України, що є експлікацією певної когнітивної моделі та слугують реалізації мовленнєвого впливу.

Виклад матеріалу. Політичний дискурс спрямований на створення певної реальності, яка вербалізує відповідну ментальність та особливим чином упорядкована відповідно до інтенцій Homo loquens як носія влади. Ця віртуальна політична реальність особливо в сучасну добу постправди вражає надзвичайною повнокровністю та здатністю заступати у свідомості людей реальну практику соціально-політичної комунікації. Безумовно, метою політичного дискурсу завжди є домінування в політичному просторі, дискредитація опонентів, завоювання прихильності авдиторії. Отже, політична реальність, сконструйована політичним дискурсом, не лише відображає спосіб інтерпретування об'єктивної реальності та експлікує ідеологічну позицію спікера, а й активно формує у свідомості людей бажаний соціально-політичний образ світу та зразки їхньої соціальної діяльності.

Надзвичайно важливою й відповідальною $є$ дискурсивна практика головного політичного лідера країни - президента, який створює систему інтерпретації політичної реальності від імені держави, пропонуючи таким чином офіційну ідеологію та визна- чаючи для адресатів політично правильну діяльність. Президентський дискурс має бути спрямований як на забезпечення суспільної консолідації та вирішення внутрішньодержавних проблем, так і на подолання викликів сучасного світу, що можуть становити загрозу національній безпеці. Урешті-решт, від успішної комунікативної практики президента країни залежить формування соціально-політичної ідентичності громадян країни та самий спосіб їхнього політичного думання.

Політичний дискурс передбачає використання мовленнєвих стратегій як сукупності запланованих ходів продуцента, спрямованих на досягнення мети. У процесі реалізації стратегії використовують різноманітні тактики, тобто конкретні мовленнєві акти, необхідні на відповідному етапі розгортання мовленнєвої стратегії. Будь-яку тактику реалізують за допомогою прийомів - способів побудови тексту або окремого висловлення 3 застосуванням відповідних лексичних засобів i синтаксичних конструкцій. Класифікацію стратегій мовленнєвого впливу, яку дослідники здійснюють за різноманітними критеріями, принципово можна обмежити двома головними опціями (як це зробив нідерландський лінгвіст Тьон Адріанус ван Дейк (Dijk, 2006): стратегія позитивної самопрезентації (грунтована на бажанні адресанта повідомлення «максимально збільшити значущість власного статусу» (Михалёва, 2009, с. 52) і стратегією негативної репрезентації опонента (спрямована на дискредитацію політичного опонента й дестабілізацію його позиції на політичній арені). До цього поділу стратегій мовленнєвого впливу Ольга Михальова додає ще стратегію театральності, орієнтовану на перформативність політичного дискурсу, на сприйняття політичної дійсності народом як деякого видовища, що спеціально для нього розігрують. Отже, уважаємо, що класифікація О. Михальової є найгрунтовнішою, оскільки описує всі можливі стратегії й тактики мовленнєвого впливу.

На нашу думку, Володимир Зеленський експлуатує переважно стратегію на підвищення та стратегію театральності, що обрані ним провідними під час виборчої кампанії та продовжують визначати (більш-менш послідовно) його політичний дискурс як Прези- 
дента України. Головною інтенцією мовленнєвих стратегій у контексті політичної риторики Президента В. Зеленського, на наш погляд, $\epsilon$ гармонізація спілкування 3 громадянами України, а саме збільшення комунікативних i перформативних актів, що максимально сприяють усуненню когнітивних суперечностей оцінки політичної ситуації. Варто додати, що стратегія театральності не могла не бути використаною чинним Президентом через його минулий досвід актора й успішного менеджера розважальних програм, яку він, отже, активно та продуктивно реалізує за допомогою апробованих тактик і прийомів мовленнєвого впливу.

Використовуючи мовленнєву стратегію на підвищення, В. Зеленський прагне створити навколо себе та тієї політичної партії, яку він привів до влади, «позитивний ментальний простір» (Михалёва, 2009, с. 57), наголошуючи на конструктивній і життєствердній ролі нової політичної сили. Найчастіше чинний Президент у виступах використовує тактику неявного позитивного аналізу (або, за класифікацією О. Михальової, тактику аналіз«плюс»), що передбачає заснований на фактах розбір ситуації, якому притаманне імпліцитне вираження позитивного ставлення продуцента висловлення до аналізованої ситуації. Без надмірної пишномовності, а також і канцеляризмів, послуговуючись усно-розмовними виражальними засобами та намагаючись дотримуватися формату зниженого буденного спілкування у звертанні до українського народу, президент розповідає йому про ініційовані владою зміни й реалізовані плани. Це саме розповідь, а не звіт чи доповідь, тому й дистанція між комунікантами (президентом і його народом) у такому випадку скорочена, а умови спілкування інтимізовані. Можна сказати, що В. Зеленський став першим українським президентом, який «зумів пояснити українцям політику краще, ніж усі депутати та президенти за 28 років» (Зе!-маркетинг...). Не будучи політичним експертом i відверто визнаючи це («Я йшов у Президенти, не маючи політичного досвіду...» (Президент України Володимир Зеленський, 2020, 4 березня), чинний український Президент ніби навчається на очах у свого народу, разом із ним і водночас у нього, відверто зізнаючись у помилках і звертаючись за підтримкою, чим, безумовно, забезпечує високі рейтинги власної популярності.

Проаналізуємо контент президентських промов, пов'язаних із пандемією коронавірусу. Протягом усіх весняних місяців 2020 р., від звернення 13 березня щодо заходів 3 протидії поширенню коронавірусу в Україні, Президент В. Зеленський регулярно, кілька разів на тиждень, звертався до свого народу. Тактика аналіз-«плюс» реалізована тут через фіксацію тих дій влади щодо запобігання поширенню хвороби та допомоги населенню в боротьбі 3 нею: «ми отримали...», «ми домовилися...», «ми працюємо над цим...», «прибув вантаж із Китаю», «вирішується питання достатнього забезпечення лікарень...» тощо. Проте продуцент висловлення в усіх контекстах утримується від позитивної оцінки перерахованих ним заходів: він обмежується позицією реєстратора позитивних змін, до того ж практично уникає негативних суджень стосовно дій попередньої влади, яка (невдало, за імпліцитною оцінкою) реалізувала медичну реформу. Натомість у всіх зверненнях В. Зеленський висловлює вдячність усім тим пересічним людям, які допомагали в протистоянні небезпечній хворобі: «Я дякую українським прикордонникам... Я дякую нашим військовим на сході України... Я дякую нашим послам і дипломатам... Нашим поліцейським та нацгвардійцям... Дякую соціально відповідальному бізнесу та нашим волонтерам... Службам таксі, які погодилися безкоштовно відвозити лікарів на роботу...» (Зеленський, 2020, 23 березня). Такі контексти есплікують значущість внеску звичайних громадян країни в боротьбу проти поширення коронавірусу (яким президент вдячний і за дотримання умов карантину), хоч, безумовно, і схвалення дій Зе-влади теж.

Стратегія театральності в політичному дискурсові В. Зеленського переважно через тактику кооперації, тобто «такий спосіб звертання до адресата, за допомогою якого мовець конструює образ останнього, апелюючи до тих ідей і цінностей, носієм яких він (на думку мовця) є» (Михалёва, 2009, с. 63). Тактика кооперації, яку використовує президент В. Зеленський і яка, власне, і забезпечила йому перемогу на виборах, виявляє себе в усіх публічних виступах політика, 
демонструючи його намір ототожнити себе 3 народом, солідаризуватися з ним у вирішенні спільних проблем, виявити майже родинний зв'язок із кожним громадянином тієї країни, яку він має честь очолювати. Значну роль у створенні позитивного іміджу чинного Президента як «свого хлопця», «вихідця з народу», який чудово розуміє та відчуває всі проблеми останнього, відіграв цілеспрямовано створений завдяки успішній маркетинговій стратегії В. Зеленського та його команди медіаконтент серіал «Слуга народу», що посвятив український народ у всі тонкощі й хитросплетіння українського політикуму. Майстерно знятий i значно розтиражований у вітчизняному телеефipi, фільм підготував майбутній електорат В. Зеленського до природного сприйняття небаченого доти в політичному житті України явища обрання президентом звичайної людини, пересічного шкільного вчителя, який не має жодного досвіду політичного адміністрування. Виборці, а згодом і прихильники новообраного Президента за інерцією сприйняли (а більшість і продовжують сприймати) В. Зеленського як зіграного ним кіногероя В. Голобородька - простого, але принципового й чесного політика, який ненавидить корупцію, не боїться змін і точно знає, як на своїй високій державній посаді бути справжнім «слугою народу».

Розглянемо детально тактику кооперації. Одним із прийомів ії реалізації є вокативи, які використовує Президент у публічних виступах, адресованих громадянам країни. Вокатив «Дорогі українці!» домінує в промовах чинного Президента: із 40 проаналізованих нами виступів він трапляється 30 разів (для порівняння: «Шановні пані та панове!» - 5 разів, «Дорогі громадяни!» - 3 рази, «Дорогі співвітчизники!» - 1 раз, «Усім привіт - 1 раз»). Така форма звертання до громадян своєї країни не лише експресивно маркована (висловлювання дружнього, теплого ставлення), вона також виконує важливу роль у конструюванні так званого «ми-дискурсу», який «має вираження в стратегіях інтеграції з будь-якою соціальною групою, співвідносних зі стратегіями номінації» (Филинский, 2002, с. 79). Аналізуючи використання вокатива 3 груповою співвіднесеністю (у нашому контексті це етнонім «українці») у контексті вербальних прийомів створення «ми-дискурсу», дослідник указує на нерозривний зв'язок останнього 3 поняттям нації як універсальної цінності в політичному житті (Филинский, 2002). Частотність уживання саме такого звернення Президентом В. Зеленським стратегічно зумовлена: його референтне співвідношення 3 «базовим оператором у системі соціальної класифікації», а також важливим «елементом політичного та символіко-ідеологічного порядку» (Verdery, 1993) забезпечує «ідентифікацію» реципієнтів висловлення 3 українським народом i закріплює цю номінацію на рівні ідеології. До того ж звернення «українці» реалізує функцію інтеграції та позитивного переживання належності до українського народу всіх, хто усвідомлює себе українцем незалежно від території проживання й громадянства.

Особливість політичного дискурсу В. Зеленського полягає в намаганні використовувати буденну мову в спілкуванні зі слухацькою авдиторією, орієнтуючись таким чином (і цілеспрямовано, і несвідомо, як носій буденної свідомості) на функціонування картини світу в повсякденній практиці суспільства. Варто зазначити, що використання живомовної практики свого народу допомогло чинному Президентові ще на етапі проведення виборчої кампанії викликати інтерес до своєї особи в традиційно найінертнішої частини виборців молоді. Подібно до Барака Обами, що його іменовано «президентом молоді», за якого проголосувало дві третини американців віком від 18 до 29 років, В. Зеленський також заручився підтримкою молодих людей до 30 років, серед яких він набрав 57\% голосів. Висока медійна мобільність чинного Президента разом зі створенням контенту мовою (молодіжної) авдиторії забезпечили (й забезпечують) йому адекватне взаєморозуміння з нею. Наголосимо в цьому контекстові на характерній для В. Зеленського «транслінгвальній креативності», яка репрезентує ціннісні орієнтири молодіжної «лінгвоспільноти як найбільш чуттєвої до зовнішніх впливів та здатної креативно ставитися до потенціалу як власної, так і чужої мови» (Чернишова, 2020, с. 142): «Ось такий український doing business» (Зеленський, 2019, 13 вересня); «Це не інформаційні приводи, які «в тренді» або «не в тренді». Це долі й життя людей» (Зеленський, 2020, 15 лютого); «Мит- 
ниця повинна збирати не лайки у фейсбуці, а кошти у державну казну» (Зеленський, 2020, 4 березня); «Набагато швидше від вірусу поширюються фейки щодо нього» (Зеленський, 2020, 18 березня); «У складні для країни часи займатися політичним хайпом - фактично дорівнює мародерству» (Зеленський, 2020, 23 березня); «...в публічний простір потрапив перший драфт змін» (Зеленський, 2020, 29 березня); «Я кажу це кожному хейтеру, який вважав своїм священним обов'язком написати гидоту на адресу українських учителів» (Зеленський, 2020, 10 квітня); «Можна скільки завгодно постити веселі меми про гарантії безпеки Будапештського меморандуму, однак це не поверне наші території», «Україна вже стає світовим IT-хабом» (Зеленський, 2020, 20 жовтня) тощо. Отже, вільне послуговування (й обслуговування) актуальним для найпрогресивнішої частини українського суспільства гібридним транслінгвальним дискурсом забезпечує чинному Президентові належний рівень «солідаризації» зі своїм електоратом.

Тут варто також закцентувати увагу й на способові дистрибуції контенту, яким здебільшого послуговується В. Зеленський і який, власне, і забезпечив йому перемогу на виборах. Ідеться про поширення чинним Президентом публічних меседжів за допомогою соціальних мереж на противагу його попередникам, яким для цього потрібне було сприяння засобів масової інформації. Американський дослідник Ч. Гарріс називає це комунікаційною стратегією соціальних мереж («social media strategy»), а президентів Б. Обаму й Д. Трампа, що активно її використовували, президентами соціальних мереж («social media president») (Harris, 2019). Щодо В. Зеленського, то й під час виборів, і після приходу до влади він зініціював зміну логістики політичної комунікації, зробивши саме соціальні мережі, а не традиційні 3МІ інструментом «доставки» до адресата необхідного контенту. «Інстаграм для Зеленського був як твітер для Трампа», - уважає український філософ і журналіст Володимир Єрмоленко, один із авторів дослідження «Інтерньюз-Україна» про роль соцмереж на виборах 2019 р. «Зеленський не просто виграв в інстаграмі, він розгромив своїх суперників: 80 відсотків політичних повідомлень на цій платформі були про нього, він розмив кор- дони між політикою і шоубізнесом», - говорить В. Срмоленко (Крутіший, ніж Трамп?...). Можна дискутувати стосовно того, наскільки значущими сьогодні є офлайнові та онлайнові ЗМІ в постачанні інформації від органів державної влади до громадян. Проте беззаперечним є той факт, що В. Зеленський являє собою новий тип політиків, які стають дедалі «віртуальнішими» в тому сенсі, що комунікацію 3 народом налаштовують без медійних посередників, використовуючи інтернет-канали та месенджери. Відомо, що чинний Президент спілкується 3 авдиторією через свій YouTube-канал, Instagram i Facebook (через які поширював і більшу частину передвиборчого контенту). Така форма політичної комунікації суттєво економить час на «доставку» повідомлення реципієнтові, допомагає зробити контент інтерактивним, привабити «персональною залученістю до авторського виробництва інформаційних та візуальних продуктів» (Русакова, 2014, с. 13), а головне, дати без фільтрів медіа від першої особи зрозумілі відповіді на складні запитання. Цікавим $є$ дослідження українського агентства зі стратегічних комунікацій та управління репутацією RMA «Комунікація Президента України у Facebook та Instagram у порівнянні із західними лідерами», здійснене на початку 2020 p. На той момент порівняно із 41 очільником держав країн Свропи (без Білорусі та Росіi), США й Канади В. Зеленський «опинився на другому місці із понад 9 млн підписників... Кількість його фоловерів перевищує сумарну кількість підписників прем'єр-міністра Канади Джастіна Трюдо (3,3 млн), президента Франції Емманюеля Макрона (1,6 млн) i канцлерки Німеччини Ангели Меркель $(1,1$ млн)» (Комунікація Президента України...). Перше місце на той момент посідав президент США Дональд Трамп (17,3 млн підписників). Актуальні дані засвідчують, що чинний Президент України залишається на другому місці за кількістю підписників в Instagram (9,3 млн), поступаючись першістю лише американському президентові Джо Байдену (18 млн). За висновками вищезгаданого дослідження, В. Зеленський очолює рейтинг голів держав щодо співвідношення кількості підписників до користувачів у країні $(83,64 \%)$. На другому місці зі значним відри- 
вом - тодішня президентка Хорватії Колінда Грабар-Китарович $\quad(31,45 \%) . \quad$ Ураховуючи зміну кількості користувачів Instagram в Україні станом на кінець 2020 р. (14 млн), відсоткове співвідношення до кількості підписників В. Зеленського становитиме $66 \%$. На нашу думку, це може свідчити, що пріоритет у цьому рейтингові дотепер залишається за чинним українським Президентом. За підсумками агентства RMA, «показник Володимира Зеленського можна пояснити його медійною популярністю, якої він досяг за час артистичної кар'єри, а також систематичною роботою із агітацією у соціальних мережах під час президентських виборів 2019 року» (Комунікація Президента України...).

Тактику кооперації використовує чинний Президент В. Зеленський також і через прийом орієнтації на життєві цінності, тобто через актуалізацію в мовленні фізіологічних, безпекових і соціальних потреб людей (здоров'я, родина, житло, зарплата, особиста безпека тощо). Гарант не просто виявляе обізнаність у тому, що турбує український народ у його повсякденному пересічному житті, а й обіцяє конкретну допомогу. Коли Президент говорить, що покращення медицини спостерігають лише ті, «хто ніколи не лежав 3 дитиною у звичайній лікарні» (Зеленський, 2019, 20 травня), реципієнти цього висловлення вірять у те, що він напевно лікував дитину в такій лікарні й на власному досвідові пересвідчився в наявності проблем у галузі охорони здоров'я. Так, чинний Президент, не оперуючи абстрактними поняттями патріотизму чи соборності, апелює натомість до найприродніших людських почуттів - любові до своєї дитини та бажання всіляко захищати й плекати іiі. Трепетне ставлення до власного шестирічного сина, у якого Президент навчається бачити світ у новому ракурсі, він поширює на молоде покоління сучасної України: В. Зеленський постійно експлікує у виступах намагання залишити в спадок майбутньому поколінню країну, гідну для життя: «У нас 3 вами попереду багато тяжкої роботи - будувати Україну, яку ми хочемо передати своїм дітям» (Зеленський, 2020, 1 травня); «ми повинні пообіцяти собі, що передамо наступному поколінню нову країну» (Зеленський, 2020, 28 червня). У промові до Дня Неза- лежності України 2020 р. Президент використав прийом розгорнутого порівняння, також грунтований на сімейних цінностях: стосунки матері й дитини зіставлено зі взаєминами України та іï громадян: «Думаю, для кожної матері головним є щастя дітей. Найперше, щоб іiі діти - українці були здоровими. Сьогодні ми робимо все можливе для подолання коронавірусу в Україні... Я також гадаю, кожна мама хоче, щоб їі діти не сварилися. Ми всі - діти України. I нікому не давати шансу посіяти між нами розбрат... Кожна мама хоче, щоб усі ії діти завжди були вдома. Так, на жаль, сьогодні за нашим сімейним столом бракує Донецька, Луганська і Криму. Та ми робимо все, щоб настав день, і вони повернулись...» (Зеленський, 2020, 24 серпня). I, нарешті, форматом новорічного привітання Президента було обрано спілкування 3 малечею, для якої створено відповідний формат сторителінгу, надано можливість висловити свої побажання й обіцяно (особисто гарантом) їх виконати. Така активна експлуатація теми майже родинного зв'язку з українцями формує відчутний наратив «батька нації», який піклується, радить, захищає від негараздів, виховує і сварить своїх дітей.

В. Зеленський використовує тактику кооперації в політичному дискурсові через прийом спільної відповідальності за гарну перспективу. Президент наполегливо експлікує думку, що лише від продуктивної діяльності кожного громадянина на благо держави залежать іiі добробут і благоденство: «Це спільна боротьба, де ми переможемо тільки разом» (Зеленський, 2020, 26 березня); «Ми всі стоїмо на сторожі демократичних цінностей і свобод» (Зеленський, 2020, 7 квітня); «Сьогодні така ситуація, коли кожен 3 нас може вберегти життя людей навколо» (Зеленський, 2020, 27 квітня); «Кожен з нас має бути невід'ємною частиною єдиного війська - i тільки тоді ми переможемо хворобу» (Зеленський, 2020, 13 травня); «Кому ж вершити розвиток кожного регіону? Тільки тобі. Господарю своєї землі. Бо Україна - це ти. Україна починається 3 тебе. Все твоє. Твої домівка, подвір'я, вулиця, село або місто, твоя область, а отже - i твоя країна» (Зеленський, 2020, 24 серпня) тощо. Сучасна вітчизняна дослідниця Олена Чорна визначає цей прийом як 
«усуспільнення відповідальності», тобто «формування у свідомості аудиторії думки про те, що за добробут держави відповідає не лише влада, а й кожен громадянин країни» (Чорна, 2013, с. 14). I хоча, на думку О. Чорної, «усуспільнити» й розділити 3 адресатом політики хочуть переважно проблеми, невдачі й відповідальність за непопулярні кроки» (Чорна, 2013, с. 14), ми вважаємо, що використання цього прийому в політичному дискурсі В. Зеленського зумовлене іншою інтенцією - толерувати відмінності: «Ми різні. Але рівні. Ми різні. Але рідні» (Зеленський, 2020, 24 серпня) та ініціювати відчуття «України в собі», тобто сприйняття турбот і радощів іiі синів і доньок як власний досвід кожного громадянина: «... це - наша спільна мрія. Але у нас $\epsilon$ і спільний біль. Кожен 3 нас загинув на Донбасі. Кожного дня ми втрачаємо кожного 3 нас. I кожен з нас - переселенець... I кожен 3 нас - заробітчанин...» (Зеленський, 2019, 20 травня); «Усією країною ми тягнули кравчучки, нарізали купони та дивились як «Багаті теж плачуть». Усією країною мали ваучери, ходили в «мальвінах», а ті, кому пощастило, 3 пейджерами... Усією країною стрибали на рекордну висоту - 6 метрів 14 сантиметрів... Усією країною змушували тремтіти грандів європейського футболу... Усією країною, від Донецька до Карпат, ми летіли до зірок разом з Леонідом Каденюком і раділи, коли у відкритому космосі вперше в історії пролунало «Ще не вмерла...»... Усією країною, в Інтернеті та біля телеекранів, були прикуті до новин зі сходу...» (Зеленський, 2019, 24 серпня). У такий спосіб чинний Президент намагається створити якнайширше коло душевної співпричетності, у якому обмінюватимуться життєвою енергією та спільно переживатимуть поразки й перемоги українські громадяни незалежно від віку, статі, віросповідання. До цього кола Президент зараховує й себе самого, демонструючи кожному українцеві свою близькість, «домашність», «звичайність» i, відповідно, обов'язок і покликання брати відповідальність за долю очолюваної ним країни.

Як бачимо з усіх наведених вище прикладів, лінгвістично «ми-дискурс», створюваний Президентом В. Зеленським завдяки тактиці кооперації, експліковано через частотне використання інклюзивного займенника «ми». Значення останнього розкриває формула «ми» = «я + ви (адресати)», отже, «ми» корелює з промовцем і всією його авдиторією, тобто «українцями», до яких постійно звертається чинний Президент.

У контексті вищезазначеного варто охарактеризувати ще одну тактику мовленнєвого вПливу, використовувану чинним Президентом у процесі реалізації стратегії театральності, - тактику іронізування. Ми зауважили, що В. Зеленський практично не піддає політичних опонентів нищівним нападам, а якщо останні й потрапляють у фокус критичного аналізу, то отримують іронічну оцінку, у дусі «кварталівського» висміювання: «Ми постійно чули про економічний стрибок, але $\epsilon$ враження, що економіка брала розгін, спіткнулась і ризикує проїхатись обличчям по землі» (Зеленський, 2020, 4 березня); «За новим механізмом деяким лікарням вистачить коштів хіба що на дверний замок i плакат: «Ми закрились. Тримайтесь. Удачі» (Зеленський, 2020, 4 травня); «Річ у тому, що в окремих політичних партій активізувався вірус, який сидить у них останні 28 років. Цей вірус має назву «хитрозробленість» (Зеленський, 2020, 6 травня). 3 наведених прикладів політичної риторики випливає, що чинний український Президент критикує опонентів здебільшого у форматі прихованої іронічної насмішки, а не відвертого саркастичного глузування. При цьому функція іронії $\epsilon$ неагресивною (коли мовленнєвий акт спрямований на руйнацію іміджу певної особи), а радше перформативною: це самопрезентація автора висловлення, його позитивне самопозиціонування як людини 3 почуттям гумору, ерудованої та кмітливої, головним засобом успішного мовленнєвого впливу якої в його «допрезидентський» час був саме гумор. Отже, ми не вважаємо, що необхідним компонентом іронії в контексті політичного дискурсу В. Зеленського $€$ негативна оцінність. Скоріше пристаємо до думки тих дослідників (як-от Ірини Шкіцької), які вважають іронію складником «маніпулятивного дискурсу позитиву», оскільки, м'яко іронізуючи над своїми політичними суперниками, В. Зеленський демонструє цим як своє бажання уникнути агресивного 
протистояння, так й імпліцитне визнання браку політичного досвіду для відвертого таврування опонентів.

Висновки. Отже, політичний дискурс Президента України Володимира Зеленського представлений переважно двома стратегіями: на підвищення й театральності, головними інтенціями яких є гармонізація спілкування 3 громадянами країни та максимальне усунення когнітивних суперечностей в оцінці політичної ситуації. Їх реалізують переважно тактики прихованого позитивного аналізу, кооперації й іронізування. Безпосереднім проявом застосування цих тактик $є$ ціла низка прийомів словесної експлікації інтенцій голови держави, тобто використання конкретних мовних засобів, за допомогою яких, власне, i конструюють тіло дискурсу, щоб, своєю чергою, породжувати політичну реальність. Дослідження показало, що президентський дискурс В. Зеленського являє собою складне багатовимірне мовленнєве утворення, характерними рисами якого є формат зниженого буденного спілкування у звертанні до українського народу; намір ототожнити себе 3 народом, солідаризуватися 3 ним у вирішенні спільних проблем, виявити майже родинний зв'язок із кожним громадянином країни; репрезентація ціннісних орієнтирів молодіжної лінгвоспільноти; поширення публічних меседжів за допомогою соціальних мереж; актуалізація в мовленні фізіологічних, безпекових і соціальних потреб людей; прийом спільної відповідальності за гарну перспективу; перформативна функція іронії.

Подальші розвідки в проблемному полі політичного дискурсу Президента Володимира Зеленського можливі в напрямі аналізу змін у стратегіях і тактиках мовленнєвого впливу залежно від трансформації соціально-політичної ситуації, зовнішніх і внутрішніх загроз національній безпеці України.

\section{ЛІТЕРАТУРА}

Гаврилова М.В. Лингвистический анализ выступлений главы государства: тематика, направления и методы исследования. Политическая наука. 2017. № 2. С. 54-72.

Диманте И.В. Инструментарий профессионального коммуникатора (приёмы речевого воздействия). Коммуникативные исследования. 2015. № 4 (6). С. 52-64.

Зе!-маркетин г: 9 висновків, які кожен маркетолог повинен зробити з перемоги Володимира Зеленського. URL: https://toplead.com.ua/ua/blog/id/marketing-zelenskogo-225/.

Комунікація Президента України у Facebook та Instagram у порівнянні із західними лідерами. URL: https://rma.team/western_leaders/.

Крутіший, ніж Трамп? Як Зеленський переконував виборців у соцмережах. URL: https://www. radiosvoboda.org/a/vyborch-kampanija-u-sotsmerezhakh/30563343.html.

Макаренко Л. Політична комунікація у демократичних процесах в Україні : монографія. Київ : Кий, 2017. $323 \mathrm{c}$.

Михалёва О.Л. Политический дискурс: Специфика манипулятивного воздействия. Москва : Книжный дом «ЛИБРОКОМ», 2009. 256 с.

Президент України Володимир Зеленський. Офіційне інтернет-представництво. Промови. URL: https://www.president.gov.ua/news/speeches.

Русакова О.Ф. Коммуникативные стратегии перформативного дискурса. Дискурс-Пи. 2014. № 1 (14). C. $12-14$.

Филинский А.А. Критический анализ политического дискурса предвыборных кампаний 1999-2000 гг. : дисс. ... канд. филол. наук : 10.02.19. Тверь, 2002. 143 с.

Чернишова Т.О. До проблеми транслінгвізму в сучасній вітчизняній лінгвістиці. Вчені записки Таврійського національного університету імені В.І. Вернадського. Серія «Філологія. Соціальні комунікаиї̈». 2020. № 1. Ч. 4. С. 138-145.

Чорна О.О. Комунікативні засоби творення іміджу політичного лідера (на матеріалі українського, російського та англійського політичного дискурсу) : автореф. дис. ... канд. філол. наук : 10.02.15. Одеса, 2013. 24 с.

Adair J. Develop your leadership skills : fast, effective ways to become a leader people want to follow. 4th Edition. New York : Kogan Page Ltd, 2019. 94 p.

Adolphsen M. Communication strategies of governments and NGOs : Engineering global discourse at highlevel international summits. Wiesbaden : Springer VS, 2014. 227 p. 
Dijk T.A. van. Politics, ideology, and discourse. The Encyclopedia of Language \& Linguistics / edited by Brown K. 2nd ed. Amsterdam ; Boston : Elsevier, 2006. Vol. 9. P. 728-740.

Discourse studies in public communication / edited by Eliecer Crespo-Fernández. Amsterdam; Philadelphia: John Benjamins Publishing Company, 2021. 323 p.

Freelon D., Wells C. Disinformation as Political Communication. Political Communication. 2020. Vol. 37. Issue 2. P. $145-156$.

Harris C. Missing the Mark: Obama and Trump's use of similar communication strategies. Political Science. 2019. Vol. 32. URL: https://scholarsarchive.library.albany.edu/honorscollege_pos/32.

Verdery K. Whither «Nation» and «Nationalism»? Daedalus. 1993. Vol. 122. Issue 3. P. 37-46.

\section{REFERENCES}

Gavrilova, M. V. (2017). Lingvisticheskij analiz vystuplenij glavy gosudarstva: tematika, napravlenija i metody issledovanija [Linguistic analysis of the speeches of the head of state: topics, directions and research methods]. Politicheskaja nauka - Political Science, 2, 54-72 [in Russian].

Dimante, I. V. (2015). Instrumentarij professional'nogo kommunikatora (prijomy rechevogo vozdejstvija) [Professional communicator's toolkit (methods of speech influence)]. Kommunikativnye issledovanijaCommunication research, 4 (6), 52-64 [in Russian].

Ze!-marketynh: 9 vysnovkiv, yaki kozhen marketoloh povynen zrobyty z peremohy Volodymyra Zelenskoho [Ze!-Marketing: 9 conclusions that every marketer must draw from the victory of Vladimir Zelensky], from https://toplead.com.ua/ua/blog/id/marketing-zelenskogo-225/ [in Ukrainian].

Komunikatsiia Prezydenta Ukrainy u Facebook ta Instagram u porivnianni iz zakhidnymy lideramy [Communication of the President of Ukraine on Facebook and Instagram in comparison with Western leaders], from https://rma.team/western leaders/ [in Ukrainian].

Krutishyi, nizh Tramp? Yak Zelenskyi perekonuvav vybortsiv u sotsmerezhakh [Steeper than Trump? How Zelensky persuaded voters on social networks], from https://www.radiosvoboda.org/a/vyborchkampanija-u-sotsmerezhakh/ 30563343.html [in Ukrainian].

Makarenko, L. (2017). Politychna komunikatsiia u demokratychnykh protsesakh v Ukraini: monohrafia [Political communication in democratic processes in Ukraine: monograph]. Kyiv: Kyi [in Ukrainian].

Mihaljova, O.L. (2009). Politicheskij diskurs: Specifika manipuljativnogo vozdejstvija [Political discourse: Specificity of manipulative influence]. Moskow : Knizhnyj dom «LIBROKOM» [in Russian].

Prezydent Ukrainy Volodymyr Zelenskyi. Ofitsiine internet-predstavnytstvo. Promovy [President of Ukraine Volodymyr Zelensky. Official online representation. Speeches], from https://www.president.gov.ua/ news/speeches [in Ukrainian].

Rusakova, O. F. (2014). Kommunikativnye strategii performativnogo diskursa [Communicative strategies of performative discourse]. Diskurs-Pi - Discourse-Pi, 1 (14), 12-14 [in Russian].

Filinskij, A. A. (2002). Kriticheskij analiz politicheskogo diskursa predvybornyh kampanij 1999 - $2000 \mathrm{gg}$. [Critical Analysis of the Political Discourse of the 1999 - 2000 Election Campaigns] (Candidate's thesis). Tver' [in Russian].

Chernyshova, T. O. (2020). Do problemy translinhvizmu v suchasnii vitchyznianii linhvistytsi [To the problem of translinguism in modern domestic linguistics]. Vcheni zapysky Tavriiskoho natsionalnoho universytetu imeni V. I. Vernadskoho. Seriia : Filolohiia. Sotsialni komunikatsii - Scientific notes of V.I. Vernadsky Taurida National University. Series : Philology. Social communications, 1, part 4, 138-145 [in Ukrainian].

Chorna, O. O. (2013). Komunikatyvni zasoby tvorennia imidzhu politychnoho lidera (na materiali ukrainskoho, rosiiskoho ta anhliiskoho politychnoho dyskursu) [Communicative means of creating the image of a political leader (based on Ukrainian, Russian and English political discourse)] (Extended abstract of candidate's thesis). Odesa [in Ukrainian]. 